\title{
Internasjonalt samarbeid om evaluering av skoleprogrammet Zippys venner
}

Ved Mette Ystgaard

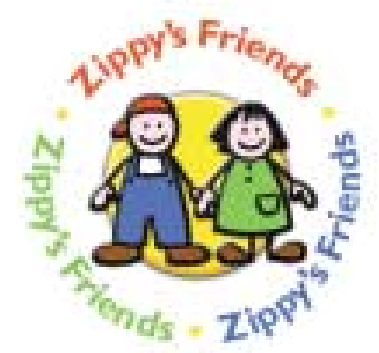

\begin{abstract}
I denne artikkelen blir metode og resultater fra evalueringer av forebyggingsprogrammet Zippys venner beskrevet. En ledende idé ved utviklingen av Zippy-programmet var at det skulle basere seg på universell teori om sammenhengen mellom mestring av livsbelastninger og psykisk helse, og at undervisningsmaterialet skulle omfatte temaer, illustrasjoner og læringsoppgaver som kunne brukes med små justeringer i ulike land og kulturer. Å se hvorvidt man lyktes i dette, var derfor en viktig problemstilling i tillegg til å se på effektene av programmet.
\end{abstract}

I mange land har skolen lang tradisjon som arena for forebyggende arbeid. "H er når vi alle", og "vi når dem tidlig", har vært tungtveiende argumenter for å sette i gang tiltak for å forebygge uttallige problemer som tidlige svangerskap og abort, hiv-aids, misbruk av rusmidler, trafikkulykker, spiseforstyrrelser, selvmordsatferd og nå i senere tid overvekt, mobbing og atferdsvansker. De senere års internasjonale kunnskapstester har på sin side ført til ønsker om flere timer i basisfagene.

Kampen om barnas undervisningstid og oppmerksomhet er derfor større en $n$ noensinne, og skolen må i økende grad prioritere i den overflod av forebyggende programmer som tilbys dem.

Ett viktig kriterium for valg av forebyggende programmer er hvorvidt bruk av programmet kan forventes å ha den ønskede effekt. Internasjonalt har man lenge vært opptatt av å vurdere virkningen av ulike forebyggen de tiltak i skolen (Durlak \& W ells, 1997; W eisz et al., 2005). I de senere år har også norske myndigheter lagt vekt på at de tiltakene som tilbys skolen, skal være kunnskapsbaserte og kunne forventes å ha effekt. For et par år siden gav Sosial- og hel sedirektoratet og U tdanningsdirektoratet en gruppe forskere innen forebyggingsfeltet i oppdrag å utarbeide en oversikt over kunnskapsstatus på dette feltet i norske skoler. Resultatene foreligger i rapporten Forebyggende tiltak i skolen ( $\mathrm{N}$ ordahl et al., 2006).

$\mathrm{H}$ er redegjør forskerne for en vurdering av 30 programmer som tilbys og drives $i$ norske skoler innen områdene rus, atferdsproblemer og sosial kompetanse. Kriteriene de vurderte programmene etter, var hvorvidt de var forankret i grunnleggende teori og/eller empiri, hadde en klart definert implementeringsstrategi og kunne vise til dokumenterte effekter. D e konkluderte med at 11 av de 30 programmene tilfredstilte evalueringskriteriene.
Skoleprogrammet Zippys venner var ett av disse. M ed unntak av det nasjonale barnehageprogrammet " D u og jeg og vi to", var dette det eneste av programmene for bruk i barnehage og småskolen som ble anbefalt. 0 gså den internasjonale faglitteraturen viser at det foreligger få programmer for barnehage og småskole som er evaluert og kan vise til dokumenterte effekter (Joseph \& Strain, 2003).

\section{Evaluering som del av programutviklingen}

Zippys venner ble utviklet av den frivillige organisasjonen Befrienders International rundt århundreskiftet. Fagpersoner fra fire land med særskilt kompetanse på forebygging ble engasjert av organisasjon en for å klargjøre det teoretiske grunnlaget og utvikle retningslinjer for programmets innhold og pedagogiske prinsipper. Programmet ble forankret i nyere teori og empiri om stressmestring, og skulle basere seg på en rekke konkrete Iæringsoppgaver som inviterte til stor grad av elevaktivitet. I forbindelse med utviklingen av programmet ble det anbefalt å gjennomføre kontinuerlig testing og revisjon av materialet når det gjaldt temaer, illustrasjoner, oppgaver, aktiviteter og rollespill. Både lærere og elever i C anada, Danmark og England var engasjerte og ga innspill.

Tilbakemel ding og testing førte til flere revisjoner før programmet forelå i sin nåværende form og ble gjort til gjenstand for en omfattende effektstudie i Danmark og Litauen ( M ishara \& Y stgaard, 2006).

\section{Effektevaluering av programmet i Litauen og Danmark}

En av programmets hovedidéer er at det med små tilpasninger skal kunne brukes i land med ulike kulturer og skolesystemer. $\mathrm{M}$ ålet med evalueringen var derfor først å se om programmet lot seg implementere i skole og barnehage i forskjellige land. Dernest var målet å vurdere om programmet faktisk hadde de forventede effekter på de som deltok.

$\mathrm{H}$ vordan ble programmet evaluert?

Programmet består av 24 timer. Både Iæringsmål, Iærerens oppgaver og elevaktiviteter er relativt detaljert beskrevet for hver time i en egen manual. I tillegg gjennomfører lærerne to dager med trening i å bruke programmet, og har minst to veiledersamlinger underveis i programperioden. For å vurdere om programmet ble implementert i henhold til planen, besvarte læreren et eget skåringsskjema etter hver time de hadde gjennomført. H er svarte de på om timen ble gjennomført, hvor mange barn som var til stede, hvor mange som var aktive, og om det ble gjort vesentlige avvik fra manualen. Videre vurderte de på en fempunkts skala hvorvidt barna likte timen, om de vurderte timen nyttig for barna, og om instruksjonen i manualen var klar og tilstrekkelig. De ble også oppfordret til å rapportere positive og negative erfaringer fra timen med egne ord. Etter å ha gjennomført programmet besvarte de nye spørsmål; denne gangen for å gi tilbakemeldinger på en fempunkts skala om helhetsinntrykket av programmet og nytten av lærertrening og veiledning.

For å studere om programmet hadde effekt, kartla man alle barna som deltok før og etter programmet. Forandringene hos barna som deltok i programmet, ble sammenlignet med forandringer hos barna i en kontrollgruppe. Kontrollgruppen var matchet på alder (klassetrinn), kjønn og sosial status.

Effektmålene ble valgt i henhold til programmets mål settinger. Programmets moduler har delmål når det gjelder å styrke sosiale ferdigheter som kommunikasjon, samarbeid, selvkontroll, empati og selvhevdelse. A lle timene har i tillegg treningsoppgaver i tilknytning til å 
håndtere eller mestre problemer som "når man ikke får være med på leken", "når bestevennen flytter" eller "når kjæl edyret dør". For å evaluere effekten av programmet på barnas sosiale kompetanse og stressmestring ble det benyttet følgende anerkjente internasjonale skalaer: Social Skills Rating Scale (G resham \& Elliot, 1990) og The Schoolagers' Coping Strategies (Ryan-W enger, 1990). A lle barna både $\mathrm{i}$ intervensjons- og kontrollgruppen ble kartlagt med de samme måleinstrumentene. Barnas lærer fylte ut skjemaene, og barna ble intervjuet av trenede intervjuere.

\section{$M$ aterialet}

Skoler og barnehager ble rekruttert av landenes lokale Zippy-organisasjoner. I Litauen meldte 16 førskoleklasser seg til å delta i programmet. I Danmark ble programmet prøvd ut i 17 førsteklasser. Det ble val gt ut 6 førsteklasser i Danmark og 6 førskoleklasser i Litauen som kontrollgrupper. Det var tilnærmet lik fordeling av gutter og jenter i hver av de fire gruppene. Tabell 1 gir informasjon om deltakerne i studien.

\section{H vordan lot programmet seg implementere?}

M ed unntak av to enkeltstående Zippytimer i Danmark ble alle timene gjennomført. Tid var et problem. M ange leksjoner måtte fordeles på to timer.

Programmets strenge struktur var mindre populær i Danmark, særlig i startfasen. Lærerne i Litauen opplevde strukturen som en god hjelp allerede fra starten.

Figur 1 viser lærernes vurdering av om barna likte hver enkelt av de 24 leksjonene. I et internasjonalt perspektiv er det interessant å se at det er stort sett sammenfallende vurderinger fra lærerne i de to landene. Kurvene viser at etter en entusiastisk start faller vurderingene i de neste timene, før de stiger noe og holder seg relativt jevnt gjennom det meste av programmet, for så mot slutten å ha en klar stigning i begge landene. I de siste populære timene repeterer, integrerer og feirer barna mye av det de har lært. Det er størst forskjell mellom landene i vurdering av time 18. I denne timen snakker de om døden, og om hvordan de har det når noen de er glad i dør. A llerede under

Tabell 1. Oversikt over antall barn og alder i kontroll- og tiltaksgruppene i skoleprogrammet Zippys venner i Litauen og Danmark

\begin{tabular}{l|c|c|c|c|c|c|c}
\hline & \multicolumn{3}{|c|}{ Litauen } & \multicolumn{3}{c|}{ Danmark } \\
\hline & $\begin{array}{c}\text { Antall } \\
\text { barn }\end{array}$ & $\begin{array}{c}\text { Alder } \\
\text { (gjennomsnitt) }\end{array}$ & $\begin{array}{c}\text { Standard- } \\
\text { avvik }\end{array}$ & $\begin{array}{c}\text { Antall } \\
\text { barn }\end{array}$ & $\begin{array}{c}\text { Alder } \\
\text { (gjennomsnitt) }\end{array}$ & $\begin{array}{c}\text { Standard- } \\
\text { avvik }\end{array}$ \\
\hline Tiltaksgruppe & 314 & 6 år, 2 mnd & $4.6 \mathrm{mnd}$ & 322 & 7 år, $5.1 \mathrm{mnd}$ & $6.8 \mathrm{mnd}$ \\
\hline Kontrollgruppe & 104 & 6 år, $0.7 \mathrm{mnd}$ & $4.9 \mathrm{mnd}$ & 110 & 7 år, $4.4 \mathrm{mnd}$ & $6.5 \mathrm{mnd}$ \\
\hline
\end{tabular}

Figur 1. Svar på spørsmålet "Likte barna denne timen?" - fra skoleprogrammet Zippys venner i Litauen og Danmark

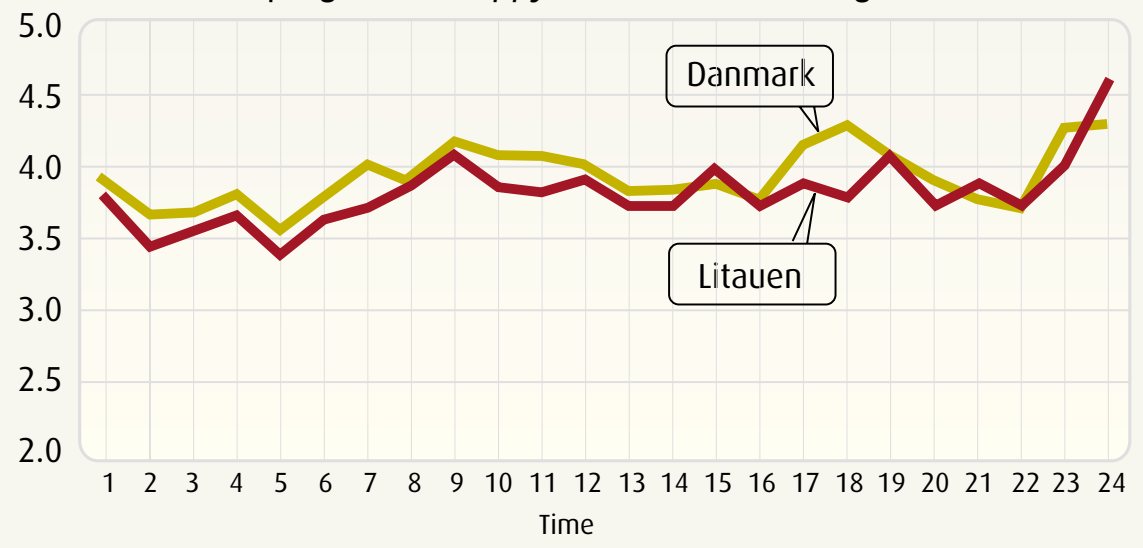

lærertreningen i Litauen mente mange at denne timen var uheldig for barn. De burde skånes fra å snakke om dette. Vi har selvsagt her bare læreres vurdering av hvorvidt elevene likte denne timen - hva el evene selv mente har vi ikke data på.

Tabell 2 på neste side viser lærernes vurdering av noen forhold om hver enkelt time og dessuten hvilket inntrykk de satt igjen med etter at programmet var avsluttet. $\mathrm{H}$ er igjen er det interessant at lærere i Litauen og D anmark vurderer svært likt. H ovedinntrykket av programmet er godt, og de er svært fornøyde med treningen før programmet startet og med veiledningen. Det er bare én signifikant forskjell. Barna i Danmark er langt mer aktive i timene enn barna i Litauen. I tillegg til disse strukturerte svarene lærte vi mye fra lærernes rapporter på de åpne spørsmålene på slutten av skjemaet. H ovedinntrykkene her var at mange både i Litauen og Danmark mente de hadde lært barna bedre å kjenne, og de hadde fått en metode for å snakke med dem når de var oppe i problemer og konflikter både i timene og i frikvarterene. $M$ ange sa også at miljøet i klassen var blitt bedre, og at de selv var blitt tryggere i sin rolle som lærer og hva de kunne snakke med barn om. $\mathrm{N}$ oen få fant seg ikke til rette med programmet. Disse innvendte særlig at det kunne være vanskelig å holde barnas oppmerksomhet over så vidt lang tid, og at enkelte timer virket for abstrakte.

B edre sosial kompetanse og flere nyttige mestringsstrategier

$\mathrm{N}$ aturlig nok observerte man forandringer i sosial kompetanse og mestringsstrategier både i kontroll- og tiltaksgruppene i løpet av skoleåret. Det skjer mye modning og læring på et år i denne aldersperioden. Desto viktigere er det å sammenlikne endring hos de barna som får programmet, med endringer hos barn på samme alderstrinn som ikke får det. $\mathrm{Vi}$ fant flere signifikante endringer i tiltaksgruppene sammenliknet med kontrollgruppene i begge landene. For det første fant vi flere indikasjoner på bedre mestring. Basert på Iærernes rapporter hadde barna i tiltaksgruppen lært seg flere 
Tabell 2. Lærernes vurdering av skoleprogrammet Zippys venner

i Litauen og Danmark

Gjennomsnitt (standardavvik)

\begin{tabular}{l|c|c} 
& Litauen & Danmark \\
\hline Lærerens vurdering av om barna likte timene $^{1}$ & $3.8(.24)$ & $3.9(.21)$ \\
\hline Antall av barna som var aktive i timene (\%) & $66.53^{*}(6.74)$ & $88.63^{*}(8.34)$ \\
\hline Lærerens vurdering av om programmet var nyttig for barna $^{1}$ & $3.9(.16)$ & $3.9(.25)$ \\
\hline Lærerens vurdering av om manualen var entydig og klar $^{1}$ & $3.3(2.0)$ & $4.3(.15)$ \\
\hline Lærerens hovedinntrykk av programmet $^{1}$ & $4.5(.63)$ & $4.1(.97)$ \\
\hline Lærerens vurdering av nytten av treningen før programmet $^{1}$ & $4.5(.51)$ & $4.65(.79)$ \\
\hline Lærerens vurdering av veiledning underveis i programmet $^{1}$ & $4.7(.51)$ & $4.3(.95)$
\end{tabular}

${ }^{1}$ Skala fra $1-5, * t=15.20, d f=23, p<.000$

mestringsstrategier i løpet av den tiden programmet varte, sammenliknet med kontrollgruppen. Videre viste intervjuene med barna at barna i tiltaksgruppen hadde lært flere mestringsstrategier som de opplevde var til hjelp for dem. I begge landene fant vi også signifikant bedring i selvkontroll og utagerende atferd i tiltaksgruppen.

I tillegg viste barna i tiltaksgruppen i Litauen en signifikant bedring i samarbeid og selvhevdelse målt med lærerobservasjon, samt selvkontroll og empati målt med intervju med barna, sammenliknet med kontrollgruppen.

Førskolebarna i tiltaksgruppen i Litauen, ble fulgt opp da de begynte på skolen for å se hvordan de tilpasset seg skolesituasjonen. Sammenlignet med en kontrollgruppe på 106 elever i første klasse som ikke hadde hatt Zippy-programmet, viste Zippy-elevene bedre tilpasning i første klasse ( M onkevieciené, M ishara \& Dufour, 2006). De innordnet seg lettere skolens rutiner og regler, fikk lettere venner, gledet seg mer til å gå på skolen og håndterte konflikter på en bedre måte.

\section{Utprøving og evaluering i flere land}

Etter den positive evalueringen i Danmark og Litauen gav Befrienders International klarsignal for å spre programmet til andre land. M ed implementeringen fulgte flere mindre evalueringer som det er redegjort for i lokale rapporter. Et samlet inntrykk fra så ulike kulturer som
Hong Kong, Southampton og Durham i England, M ontreal i C anada og São Paulo i Brasil, er at programmet er lett å implementere og til passe landenes skolehverdag. Videre rapporteres det om entusiastiske barn som engasjerer seg, om lærere som synes programmet er konkret og praktisk og lett å bruke, og om foreldre som mener å observere endringer på hjemmebane. N oen få har også gjort mindre effektevalueringer og viser til styrket mestring og evne til å sette ord på følelser. $M$ en disse studiene har for svake design til at vi kan trekke sikre konklusjoner om effekter. D et er særlig viktig å merke seg at så langt er det skoler og lærere som ønsker seg programmet og dermed er positivt innstilt i utgangspunktet, som har gitt tilbakemeldinger. Flere og større studier med bedre design er nødvendig for å kunne trekke sikrere konklusjoner. Det er derfor gl edelig at både H ong Kong og I rland planlegger større eval ueringer av Zippy-programmet. $\mathrm{Og}$ i N orge er vi allerede godt i gang.

\section{Evaluering av Zippys venner i Norge}

Den norske undersøkelsen blir gjennomført ved Regionsenter for barn og unges psykiske helse, H elseregion Øst og Sør med $M$ ette Y stgaard som prosjektansvarlig og Solveig $\mathrm{H}$ olen som forskningsstipendiat.

\section{Flere problemstillinger}

Studien i N orge vil naturlig nok først og fremst se på de samme sentrale problemstillingene som i Danmark og Litauen, nemlig om programmet lar seg implementere og om det har innvirkning på barnas mestring, sosiale kompetanse og psykiske helse. M ed bakgrunn i nyere kunnskap og erfaringer fra studien i Danmark og Litauen, vil vi også se på nye problemstillinger. For det første vil vi se om programmet har ulik innvirkning på subgrupper, som barn som er særlig risikoutsatt og barn med etnisk minoritetsbakgrunn, og naturligvis også om det har ulik innvirkning på gutter og jenter. Dernest vil vi se om bruken av programmet fører til bedre sosialt miljø i klassen. $0 \mathrm{~g}$ til slutt vil vi ved å følge barna ett år etter avsluttet program vurdere om effekter som vi eventuelt finner, varer over tid.

\section{F orbedring av forskningsdesign}

For å belyse disse problemstillingene på best mulig måte har vi valgt et randomisert design. Det vil si at vi har valgt tilfeldig (ved loddtrekning) blant de skolene som ønsker å starte med programmet, hvilke skoler som skulle være kontrollog tiltaksskoler. På den måten får vi kontroll på flest mulig av de konkurrerende forholdene som kan påvirke resultatet. For eksempel kan man innvende at de positive resultatene i Danmark og Litauen skyldes lærernes iver etter å ha og drive programmet snarere enn selve programmet. Lærerne i kontrollgruppen hadde jo ikke meldt interesse for å ha programmet.

Den norske studien omfatter flere barn og skolegrupper. Såkalte styrkeberegninger antyder at vi bør ha mellom 35 og 40 skoler, i overkant av 1400 elever, for å svare på våre problemstillinger om effekter på spesielle grupper og på klassemiljø. Vi har også forbedret designet ved å samle informasjon om det enkelte barn fra både Iærere, barna selv og foreldrene. Lærere og elever fyller i tillegg ut et skjema om klassemiljøet.

Prosjektet blir giennomført i barneskoler i Bodø og i Sør-Trøndelag og $\varnothing$ stfold fylke i skoleåret 2007/08. O mrådene er valgt fordi "P sykisk helse i skolen" satser her i samme tidsperiode. Etter informasjonsmøter på ledelses- og lærernivå har i alt 35 skoler med til sammen 1480 elever, fordelt på 91 grupper på andre trinn, meldt seg interessert i å delta i forskningsprosjektet. 
Disse er trukket tilfeldig til kontroll- og tiltaksskoler. Den første datainnsamlingen ble gjennomført før høstferien i 2007. Tiltaksskolene begynte med Zippy-programmet etter høstferien. De ukentlige lærerrapportene så langt tyder på at programmet i det alt vesentlige tas godt imot på tiltaksskolene også i Norge.

\section{Avsluttende kommentar}

Det er en stor utfordring å utvikle gode forebyggende tiltak for skolen. De må oppleves som nyttige og falle naturlig inn i skolens hverdag, og samtidig ha de tilsiktede effekter for barna som deltar. Evalueringene av Zippy-programmet så langt er løfterike. Programmet tas godt imot og passer naturlig inn i skolens $\varnothing$ vrige aktiviteter og planer i land med ulike kulturer og skolesystemer. Og de foreløpige evalueringene indikerer at programmet virker. Men Zippy-programmets framtid er likevel usikker. Mer forskning og sikrere konklusjoner om programmets innvirkning på barna som deltar, vil antakelig være en viktig faktor for at programmet velges i framtiden. Like viktig er det at programmet forankres i kommunens og skolenes planer, og at lærere opplever at de får noe igjen for innsatsen. Den norske studiens vurdering av om programmet har betydning for elevenes klassemiljø, er i denne sammenhengen spennende. Dersom programmet gir bedre og tryggere klasseklima, som også betyr mye for barnas læring, vil kanskje sjansene for å ta program inn som en permanent del av skolens planer styrkes.

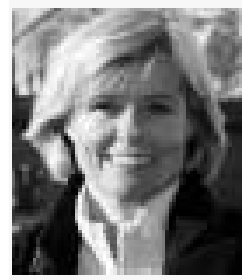

M ette Y stgaard er cand.paed. og forskningsleder ved Regionsenter for barn og unges psykiske helse, helseregion Øst og Sør. Hun er prosjektleder for evalueringen av Zippys venner i Norge.

\section{Referanser}

Durlak, J., A., \& Wells, A., M. (1997). Primary prevention mental health programs for children and adolescents: a meta-analytic review. American Journal of Community Psychology, 25, 115-152.

Gresham, F. M. \& Elliot, S. N. (1990). Social skills rating system. Circle Pines, MN: American Guidance Service.

\section{Zippys venner i Norge: nasjonal tilpasning og tverrfaglig samarbeid} v/ Nina Grindheim

Zippys venner er nå spredt til 168 skoler i landet, og neste år vil det være flere enn 250 skoler som har tatt programmet i bruk. En av grunnene til at det er så lett å få spredt programmet, er at det har sammenfallende mål med Kunnskapsløftet når det gjelder barns personlige utvikling og sosiale kompetanse. Det er Voksne for Barn som har ansvaret for implementeringen av Zippys venner i Norge.

Den norske tilpasningen av programmet innebærer at skolehelsetjenesten og PP-tjenesten involveres. Ved å gi disse tjenestene tydelige roller og oppgaver mener vi at programmet Zippys venner kan gi grunnlag for et reelt tverrfaglig samarbeid. Allerede i første klassetrinn m $\varnothing$ ter barna representanter for disse tjenestene i en naturlig sammenheng, og det kan senke terskelen for barna hvis de skulle få behov for å opps $\varnothing$ ke dem.

Utfordringen har vært å finne en forankring i de ulike tjenestenes målsettinger og planer. Det finnes en rekke ulike plandokumenter. Det er statlige planer som angir mål om tverrfaglig samarbeid om barn og unges psykiske helse, som 0 pptrappingsplanen for psykisk helse (2002), Helsedirektoratets og Utdanningsdirektoratets satsning Psykisk helse i skolen og veilederen Psykisk helsearbeid for barn og unge i kommunene (2007). I læreplanverket omtales lærernes og skolens rolle i å fremme elevenes personlige utvikling, identitet og sosiale kompetanse. Opplæringsloven pålegger PP-tjenesten å bidra til å styrke barn og unges utviklingsmuligheter og psykiske helse. I veilederen til forskriften Kommunenes helsefremmende og forebyggende arbeid i helsestasjon- og skolehelsetjeneste (2003) fremheves det at helsepersonell i

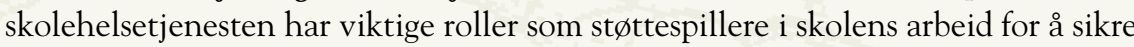
elevene både et godt fysisk og psykisk lærings- og oppvekstmiljø. Både skolen, skolehelsetjenesten, PP-tjenesten og kommunene har med andre ord målsettinger og planer som programmet Zippys venner kan forankres i.

Læreren har ansvar for den praktiske gjennomføringen av programmet. Skolehelsetjenesten deltar i timene på litt forskjellig måte på ulike steder. De kan f.eks. følge én modul (4 timer) i én gruppe og deretter følge en annen gruppe i neste modul. Det understrekes at helses $\varnothing$ ster bør ha en aktiv rolle i timene slik at hun blir en person som barna forholder seg til og blir kjent med. PP-tjenesten har ansvar for å veilede lærerne tre ganger i løpet av programmet. Mindre skoler går sammen i veiledningsgrupper. Programlojaliteten i Zippys venner er god - det er få skoler som har sluttet med programmet i de knapt fire årene det har blitt gjennomført i Norge. En av de viktigste tilbakemeldingene er at lærerne opplever programmet som nyttig. Zippys venner formidler mestringsferdigheter og ressurs- og løsningsorienterte holdninger. Dette samsvarer med sentrale verdier i lærernes pedagogiske virksomhet. Programmet har dessuten gitt lærerne trygghet i forhold til å takle vanskelige situasjoner med elevene.

$\mathbf{N}$ ina $\mathbf{G}$ rindheim er cand.paed.spec. og nasjonal programleder for Zippys venner.

Joseph, G. E., \& Strain, P. S. (2003). Comprehensive evidence-based social-emotional curricula for young children. Topics in Early Childhood Special Education, 23, 65-76

Monkeviciené, O., Mishara, B. M. \& Dufour, S. (2006). Effects of the Zippy's F riends Programme on children's coping abilities during transition from kindergarten to Elementary School. Early Childhood Education Journal, 34 (1), 55-60.

Mishara, B.L., \& Ystgaard, M. (2006). Effectiveness of mental health promotion to improve coping skills in young children: Zippy's F riends. Early Childhood Research Quarterly, (21), 110 123.
Nordahl, T., Gravrok, $\varnothing$., Knudsmoen, H., Larsen, T. M. B., \& Rørnes, K. (red.) (2006). Forebyggende innsatser i skolen. Rapport fra forskergrupper oppnevnt av Utdanningsdirektoratet og Sosial- og helsedirektoratet om problematferd, rusforebyggende arbeid, læreren som leder og implementeringsstrategier. Oslo: Utdanningsdirektoratet.

Ryan-Wenger, N. (1990). D evelopment and psychometric properties of the Schoolager' C oping Strategies Inventory. Nursing Research, 39 (6), 344-349.

Weisz, J. R., Sandler, I. N., Durlak, J. A. \& Anton, B. S. (2005). Promoting and protecting youth mental health through evidence-based prevention and treatment. American Psychologist, 60 (6), 628-648. 